\title{
Differential Ganciclovir-Mediated Cytotoxicity and Bystander Killing in Human Colon Carcinoma Cell Lines Expressing Herpes Simplex Virus Thymidine Kinase
}

\author{
PAUL D. BOUCHER, ${ }^{1}$ RANDALL J. RUCH, ${ }^{2}$ and DONNA S. SHEWACH ${ }^{1}$
}

\begin{abstract}
The two human colon carcinoma cell lines HT-29 and SW620, which stably express herpes simplex virus thymidine kinase (HSV-TK), are sensitized to the cytotoxic effects of the antiviral drug ganciclovir (GCV). Compared with HT-29 cells, SW620 cells were more sensitive to lower GCV concentrations $(<1 \mu M)$, accumulated GCV triphosphate more rapidly, and incorporated higher levels of GCV into DNA. Following a 24hr exposure to $10 \mu M \mathrm{GCV}$, bystander killing was as much as sixfold greater in SW620 cells than HT-29 cells. This bystander effect was dependent on the level of HSV-TK expression, the number of cells expressing HSVTK, and the overall confluency of the cells. However, bystander killing did not correlate with gap junctional intercellular communication as determined by microinjection of Lucifer Yellow fluorescent dye. SW620 cells were coupled to $<3 \%$ adjacent cells (compared with $>50 \%$ for HT-29 cells), but were still able to transfer phosphorylated GCV to bystander cells as soon as $4 \mathrm{hr}$ after drug was added. These results emphasize the importance of cell-specific metabolism in HSV-TK/GCV-mediated cytotoxicity and may suggest a novel mechanism for bystander killing.
\end{abstract}

\section{OVERVIEW SUMMARY}

The transfer of HSV-TK into tumor cells and the subsequent sensitization to GCV have resulted in successful antitumor effects both in vitro and in vivo for a variety of cancers. This study focuses on evaluating and comparing two colon carcinoma cell lines for their ability to metabolize GCV and transfer phosphorylated metabolites to neighboring non-HSV-TK-expressing cells (bystander effect). Here we demonstrate differences in HSV-TK expression, GCV triphosphate accumulation, and incorporation into DNA and their effect on cytotoxicity. We also provide evidence of the transfer of phosphorylated GCV to bystander cells in a cell line deficient in gap junctional intercellular communication.

\section{INTRODUCTION}

$\mathbf{T}$ THE MAJOR IMPETUS for the development of enzyme-prodrug strategies for cancer therapy is the prospect of selectively sensitizing tumor cells to a drug that is nontoxic to normal cells. Several different approaches have been reported in which a viral or bacterial enzyme (encoded by a suicide gene) is introduced into cancer cells and allows them to activate normally innocuous compounds to cytotoxic forms (Mullen et al., 1992; Moolten, 1994; Bridgewater et al., 1995). One such strategy involves transfer of the cDNA for the herpes simplex virus thymidine kinase (HSV-TK) gene into tumor cells; the gene then sensitizes the cells to the antiviral drug ganciclovir (GCV) (Moolten, 1986). Tumor cells expressing this viral kinase are able to phosphorylate ganciclovir to its cytotoxic metabolite. At first glance, this strategy would appear to be limited by the number of cells that can be transduced, since phosphorylated ganciclovir is unable to diffuse freely across the plasma membrane. However, this form of therapy is made more effective by a phenomenon termed the bystander effect. The bystander effect describes the ability of a small percentage of HSV-TK-expressing cells to sensitize non-HSV-TK-expressing cells to GCV, and is responsible for the eradication of a tumor when only a fraction of the cells are transduced with HSV-TK (Moolten, 1986; Freeman et al., 1993; DiMaio et al., 1994). This form of

\footnotetext{
${ }^{1}$ Department of Pharmacology, University of Michigan Medical Center, Ann Arbor, MI 48109

${ }^{2}$ Department of Pathology, Medical College of Ohio, Toledo, OH 43699.
} 
treatment has been successful in vitro with many different types of tumor cells and resulted in marked tumor regression in several animal models (Ezzeddine et al., 1991; Caruso et al., 1993; Ram et al., 1993; Vile and Hart, 1993; DiMaio et al., 1994; Ido et al., 1995; O'Malley et al., 1995; Yoshida et al., 1995). It is because of these promising results that approved protocols for clinical trials involving this form of gene therapy have been initiated for the treatment of brain and ovarian tumors (reviewed in Roth and Cristiano, 1997).

While HSV-TK/ganciclovir gene therapy has proven to be an effective strategy for treating some cancers in animal models, relatively little is understood about the basic mechanism of ganciclovir cytotoxicity and the bystander effect in tumor cells. Most of the information regarding the mechanism of ganciclovir comes from the analysis of its antiviral activity in the treatment of herpes simplex virus and cytomegalovirus infection (Field $e t$ al., 1983; Martin et al., 1983; Biron et al., 1985; Faulds and Heel, 1990). While these studies are informative, they may not represent the cytotoxic mechanisms occurring in HSV-TK-expressing and nonexpressing mammalian cells. In HSV-TK-expressing cells, ganciclovir is preferentially phosphorylated to its triphosphate derivative, which then competes with endogenous dGTP pools for incorporation into DNA (Balzarini et al., 1993). The presence of two hydroxyl groups on the acyclic moiety allows incorporation of GCV monophosphate internally into nascent DNA (St. Clair et al., 1987). Ganciclovir triphosphate is a potent inhibitor of viral DNA polymerase and viral DNA synthesis and, compared with other related nucleotide analogs, is a selective inhibitor of mammalian $\delta$ polymerase (Smee $e t$ al., 1985; St. Clair et al., 1987; Ilsley et al., 1995). Previous studies performed in our laboratory and using rat glioblastoma cells established that ganciclovir displays unique properties when compared with other, structurally related nucleoside analogs such as acyclovir and arabinofuranosylthymine (araT) (Shewach et al., 1994b). Of these drugs, only ganciclovir elicited a 4- to 5-log cell kill (Shewach et al., 1994b). Since such a powerful cytotoxic agent could have a major impact on the treatment of cancer, understanding and characterizing its metabolism in human tumor cells will be important for optimizing its therapeutic efficacy.

Equally important in understanding the mechanism of GCV cytotoxicity in HSV-TK-expressing cells is the bystander effect, which mediates cytotoxicity in neighboring cells that lack HSV-TK. Several theories have been proposed to explain the observed bystander killing in vitro or in vivo. They include (1) transfer of phosphorylated GCV via gap junctional intercellular communication (GJIC), (2) phagocytosis by non-HSV-TKexpressing cells of apoptotic vesicles containing GCV metabolites from HSV-TK-expressing tumor cells, (3) destruction of tumor vasculature, and (4) induction of an immune response against the tumor (Bi et al., 1993; Ram et al., 1993; Freeman et al., 1993, 1995; Samejima and Meruelo, 1995; Ramesh et al., 1996). Since current methodologies for transducing genes in vivo allow only a small proportion of the tumor to actually express HSV-TK, bystander killing is critical for the successful eradication of tumors. Elucidating these mechanisms may offer new strategies for improving the clinical application of HSV-TK/GCV gene therapy.

Although there are numerous reports of the antitumor effect of ganciclovir, none has examined the metabolism of GCV in relationship to its cytotoxicity. Outside of isolated reports on the transport and phosphorylation of GCV, reports of the pharmacodynamics of GCV in uninfected tumor cells are largely lacking (Mahony et al., 1991; Agbaria et al., 1994; Ishii-Morita et al., 1997). Therefore, we have undertaken a detailed study of the metabolism of GCV in tumor cell lines.

Suicide gene therapy has been proposed as a novel treatment for colon cancer metastatic to the liver (Huber et al., 1991, 1993; Caruso et al., 1993; Hirschowitz et al., 1995). Here we have evaluated two colorectal carcinoma cell lines for their sensitivity to GCV. Adenoviral transduction of HSV-TK rendered these cell lines sensitive to GCV with bystander killing. We have subsequently developed clonal sublines that stably express HSVTK. While all clones were sensitive to GCV, clones derived from the same cell type exhibited as much as a 10-fold difference in cytotoxicity. The availability of these stably transduced cell lines, which vary in their response to ganciclovir, allowed us to examine the underlying parameters conferring sensitivity to ganciclovir. In addition, HT-29 and SW620 cells differ in their capacities for GJIC and, therefore, allowed us to investigate the importance of this function in bystander killing.

\section{MATERIALS AND METHODS}

\section{Cell culture and generation of stable cell lines}

The human colon carcinoma cell lines HT-29 and SW620 were cultured in McCoy's 5A medium supplemented with $L^{-}$ glutamine and $10 \%$ fetal bovine serum (GIBCO-BRL, Grand Island, NY). Cells were maintained in exponential growth in a humidified incubator at $37^{\circ} \mathrm{C}$ in atmosphere of $5 \% \mathrm{CO}_{2}$ and $95 \%$ air.

HT-29 and SW620 clonal cell lines, which stably expressed HSV-TK, were developed from their parental cell line by use of a retrovirus vector containing the CDNA for HSV-TK under control of the $5^{\prime}$ long terminal repeat sequence and the aminoglycoside phosphotransferase gene for selection with the neomycin analog G418 (a generous gift from B. Davidson, University of Iowa, Iowa City, IA). Amphotropic retroviral producer cells (PAT 2.4 NIH 3T3; from B. Davidson) were grown to approximately $70 \%$ confluency, at which time the supernatant was harvested, filtered, and pipetted onto HT-29 and SW620 cultures in the presence of $8 \mu M$ Polybrene. The viruscontaining medium was removed and replaced with fresh medium $24 \mathrm{hr}$ later. After 2 days of culture, the cells were passaged and grown in culture medium containing G418 (800 $\mu \mathrm{g} / \mathrm{ml}$ ) for approximately 2 weeks. Those cells surviving selection were diluted to produce monoclonal colonies. Ten clones were derived from each cell line and maintained in G418 (400 $\mu \mathrm{g} / \mathrm{ml})$. HT-29 and SW620 clonal cell lines stably expressing $\beta$-galactosidase were developed similarly using an AdRSVlacZ vector (a generous gift from J. Maybaum, University of Michigan, Ann Arbor, MI) and verified by a chromogenic assay (see below).

SW620 cells expressing the pHook single-chain antibody were produced by stable transfection. Parental SW620 cells were plated onto $60-\mathrm{mm}$-diameter culture dishes at a density of $10^{5}$ cells/dish and grown overnight. Cells were transfected with $5 \mu \mathrm{g}$ of pHook-2 vector (Invitrogen, Carlsbad, CA) and $20 \mu \mathrm{l}$ 
of Lipofectin in $2 \mathrm{ml}$ of Opti-MEM I medium (GIBCO-BRL). Following a 24-hr incubation, the DNA-containing medium was removed and the cells were allowed to grow an additional 24 hr. Cells were subcultured and grown 2 weeks in G418 (800 $\mu \mathrm{g} / \mathrm{ml}$ )-containing selection medium. Surviving cells were subjected to magnetic separation and dilution. Monoclonal populations were derived and maintained in G418 $(400 \mu \mathrm{g} / \mathrm{ml})$.

\section{In vitro adenoviral transduction}

Construction of adenovirus vectors has been reported previously (Shewach et al., 1994b). Parental HT-29 and SW620 cells were plated at a density of $0.5 \times 10^{5}$ cells $/ 25-\mathrm{cm}^{2}$ flask and allowed to grow for $48 \mathrm{hr}$. Culture medium was removed, the cells were rinsed twice in serum-free medium, and Ad.RSVtk was added at a multiplicity of infection (MOI) of either 10 or 100 in $5 \mathrm{ml}$ of serum-free McCoy's $5 \mathrm{~A}$ medium. Following a 4-hr incubation, culture medium was supplemented with fetal bovine serum to a final concentration of $2 \%$ and grown overnight. Adenovirus-containing medium was removed, and the cells were rinsed twice with medium containing $10 \%$ serum and allowed to grow in complete medium for an additional 24 $\mathrm{hr}$ before being subcultured for cytotoxicity assays.

\section{Cell survival assays}

Colony formation assays were utilized to test for the presence of HSV-TK and sensitivity to ganciclovir (Shewach et al., 1994b). Culture flasks $\left(25 \mathrm{~cm}^{2}\right)$ were plated with 0.5 to $1 \times$ $10^{6}$ HT-29 or SW620 cells at least $24 \mathrm{hr}$ before exposure to drug. Exponentially growing cells were treated with 0.01 to 10 $\mu M$ ganciclovir (Cytovene; Syntex, Palo Alto, CA) for 2 to 24 hr. Cells were tryspinized, counted with a Coulter (Hialeah, FL) electronic particle counter, and diluted to approximately $100 \mathrm{vi}$ able cells per 35 -mm-diameter well in six-well culture dishes. After 10-14 days the resulting cell colonies were fixed in methanol-glacial acetic acid $(3: 1, \mathrm{v} / \mathrm{v})$, stained with $0.4 \%$ crystal violet, and visually counted. Cell survival was expressed as a fraction of plating efficiency for untreated cells. All colony formation assays were performed independently at least twice and each point was plated at least in triplicate. Data are reported as the mean \pm standard error of the mean (Zar, 1974).

\section{$X$-Gal staining of $\beta$-galactosidase-expressing cells}

In experiments in which bystander cell survival was measured, a chromogenic assay was utilized to determine the number of surviving $\beta$-galactosidase-expressing cells (Lim and Chae, 1989). Colony formation assays were performed as described above, except that surviving colonies were fixed for 15 min in $2 \%$ glutaraldehyde, washed with phosphate-buffered saline (PBS), and stained with $0.2 \%$ 5-bromo-4-chloro-3-indolyl- $\beta$-D-galactoside (X-Gal; Boehringer Mannheim, Indianapolis, IN). Blue-stained colonies were visually enumerated.

\section{Isolation of total RNA and Northern analysis}

Total RNA from HT-29 clones 4, 8, and LacZ and from SW620 clones 2,3 , and LacZ was extracted from $70 \%$ confluent cultures in $100-\mathrm{mm}$ culture dishes using TRIzol reagent (GIBCO-BRL). An equal amount of total RNA $(20 \mu \mathrm{g})$ was loaded onto a $1 \%$ agarose gel and separated by electrophoresis.
RNA was transferred to a Hybond-N+ nylon membrane (Amersham, Arlington Heights, $\mathbb{L}$ ) by capillary action overnight in $20 \times \mathrm{SSC}$ ( $1 \times$ SSC is $0.15 \mathrm{M} \mathrm{NaCl}$ plus $0.015 \mathrm{M}$ sodium citrate). The membrane was cross-linked and prehybridized with $5 \times$ Denhardt solution, $5 \times$ SSC, $0.5 \%$ sodium dodecyl sulfate (SDS), and salmon sperm DNA (10 $\mu \mathrm{g} / \mathrm{ml})$. The blot was then hybridized overnight at $65^{\circ} \mathrm{C}$ with $\left[\gamma^{32} \mathrm{P}\right] \mathrm{dCTP}$-radiolabeled HSV-TK cDNA prepared using a random primer DNA-labeling system (GIBCO-BRL). The blot was washed three times with $2 \times \mathrm{SSC}$ and $0.1 \%$ SDS at $65^{\circ} \mathrm{C}$, subjected to autoradiography, and developed after exposure for $1-2$ days at $-70^{\circ} \mathrm{C}$.

\section{Analyses of cellular GCV nucleotides}

Clonal cell lines were characterized for their ability to accumulate phosphorylated ganciclovir, using a nucleotide pool assay described previously (Shewach et al., 1994a). Briefly, cells were treated for 2 to $24 \mathrm{hr}$ with $1 \mu M \mathrm{GCV}$ containing $\sim 10 \%\left[8-{ }^{3} \mathrm{H}\right]$ ganciclovir (Moravek Biochemicals, Brea, CA), harvested by trypsinization, and counted. Cellular nucleotides were extracted with ice-cold $0.4 N$ perchloric acid. The phosphorylated derivatives of ganciclovir were separated from endogenous nucleotides and quantitated by strong anion-exchange high-performance liquid chromatography (HPLC) using a Waters (Milford, MA) gradient system composed of two model 501 pumps, a U6K injector module, and a model 996 photodiode array detector; the system was controlled by Millenium 2010 software. Before injection, each sample was spun at $12,000 \times g$ for $5 \mathrm{~min}$ to remove particulate matter and the $\mathrm{pH}$ was adjusted to $\mathrm{pH} 2.8$ to match the starting elution buffer $\mathrm{pH}$. Samples were loaded onto a 5- $\mu \mathrm{m}$ Partisphere $4.6 \times 250 \mathrm{~mm}$ SAX column (Whatman, Hillsboro, OR) and nucleoside triphosphates were eluted with a linear gradient of ammonium phosphate buffer ranging from $0.15 M, \mathrm{pH} 2.8$, to $0.6 M$, pH 3.8. Ganciclovir triphosphate was resolved completely from the endogenous nucleotides by these procedures. Retention times for the nucleotide triphosphates were as follows: CTP/dCTP, $20 \mathrm{~min}$; UTP, $21.5 \mathrm{~min}$; dTTP, $22.0 \mathrm{~min}$; ATP, $26.0 \mathrm{~min}$; dATP, $28.3 \mathrm{~min}$; GCV triphosphate, $29.8 \mathrm{~min}$; GTP, $32.1 \mathrm{~min}$; and dGTP, $33.0 \mathrm{~min}$. Nucleotides were identified on the basis of their ultraviolet spectrum over the range of $200-355 \mathrm{~nm}$ and by coelution with authentic standards. Cellular nucleotides were quantitated by comparison of their peak areas with that of a known amount of the appropriate standard at wavelengths 254 and 281. Fractions containing radiolabeled ganciclovir nucleotides were collected and quantitated by liquid scintillation spectrometry on the basis of the known specific activity of the tritiated ganciclovir.

The acid-insoluble cell pellets were washed with $0.4 \mathrm{~N}$ perchloric acid and solubilized overnight in $1 \mathrm{~N} \mathrm{KOH}$. Incorporation of $\left[{ }^{3} \mathrm{H}\right] \mathrm{GCV}$ into DNA was then estimated by quantitating the amount of radiolabeled GCV by liquid scintillation spectrometry. Isolation of cellular DNA and RNA fractions separately demonstrated that $\geq 97 \%$ of the tritium was associated with DNA, whereas RNA contained only background levels of tritium (data not shown).

\section{Separation of pHook-expressing cells}

Mixtures of SW620 cell lines expressing pHook and HSVTK were plated onto 35 -mm-diameter six-well culture dishes 
at a density of 0.5 to $1 \times 10^{6}$ cells/dish and grown overnight. Following radiolabeled drug treatment, cells were harvested with PBS-3 $\mathrm{m} M$ EDTA and pipeted to achieve a single-cell suspension. Cells were then rotated for $30 \mathrm{~min}$ in $1 \mathrm{ml}$ of complete medium in the presence of $3 \times 10^{6}$ magnetic beads coated with 4-ethoxymethylene-2-phenyl-2-oxazolin-5-one (phOx, Capture-Tec Beads; Invitrogen). pHook expressing cells produce an extracellular single-chain antibody directed toward phOx, allowing the physical separation of these cells with a magnet (Griffiths et al., 1984; Hoogenboom et al., 1991; Coloma et al., 1992). Tubes containing the cells were placed in a magnetic stand and mixed for $2 \mathrm{~min}$. Cells not bound to magnetic beads were removed. The bound cells were extensively washed, resuspended in $1 \mathrm{ml}$ of complete medium, and counted before being subjected to nucleotide pool analysis.

\section{RESULTS}

\section{Sensitization of colon carcinoma cells following adenoviral transfer of HSV-TK}

To determine the feasibility of HSV-TK/ganciclovir gene therapy for colorectal carcinoma, primary (HT-29) and metastatic (SW620) human adenocarcinoma cell lines were transduced with an adenovirus vector containing the HSV-TK gene. Both cell lines were rendered sensitive to ganciclovir at MOI of 10 and 100 (Fig. 1). Cytotoxicity was dose dependent and increased with increasing MOIs in both cell lines. SW620 cells were more sensitive to lower concentrations of ganciclovir, with an $\mathrm{IC}_{50}(50 \%$ cytotoxic concentration) of $0.06 \mu M$ compared with $0.25 \mu M$ for HT-29 cells. HT-29 cells treated with a higher

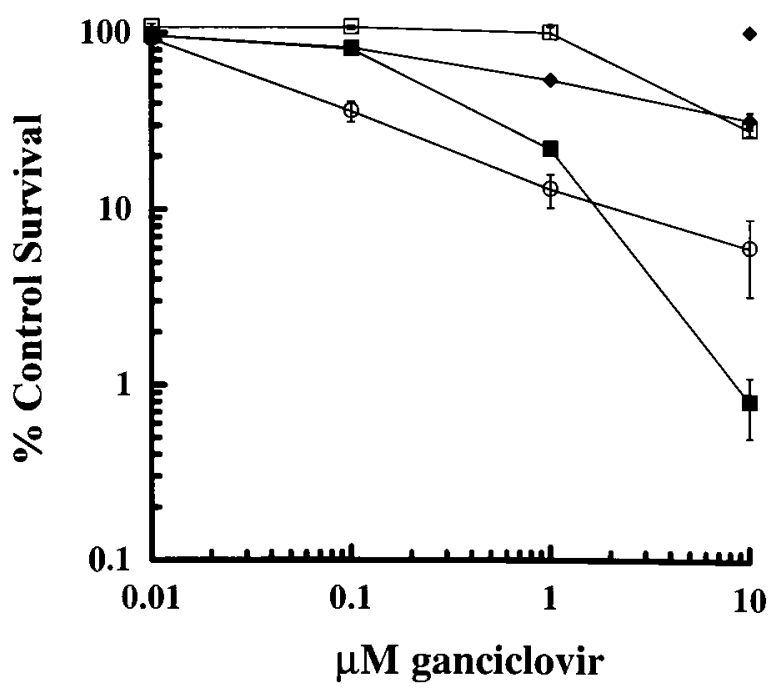

FIG. 1. Cytotoxicity after adenoviral transduction in HT-29 (squares) and SW620 (circles) colon carcinoma cells. Cells were transduced with Ad.RSVtk at MOIs of 10 (open symbols) or 100 (closed symbols). Cell survival was determined by colony formation assay following a 24-hr exposure to increasing concentrations of GCV. Cells transduced with Ad.RSVlacZ served as a control (diamonds). Values represent the mean \pm SEM of triplicate samples from two separate experiments. ganciclovir concentration $(10 \mu M)$ achieved an approximately 1-log greater cell kill than did SW620 cells. In parallel experiments using an adenovirus vector containing the $l a c Z$ gene in place of HSV-TK, the level of transduction for both cell lines was estimated to be 0.5 and $5 \%$ for MOIs of 10 and 100 , respectively (data not shown). Although this may underestimate the number of cells expressing HSV-TK, these experiments at an MOI of 10 suggests that some bystander killing of nontransduced cells occurred.

\section{Development and sensitivity of stable HSV-TK-expressing HT-29 and SW620 clones}

To study the role of HSV-TK expression and/or metabolism in the cytotoxicity of ganciclovir, clonal cell populations of both HT-29 and SW620 cell lines that stably express HSV-TK were developed using a retrovirus vector containing the cDNA for HSV-TK and a neomycin resistance gene. Ten G418-resistant monoclonal sublines from each parental cell type were assayed for the presence of HSV-TK and sensitivity to ganciclovir. The range of cytotoxicity represented by four clones from each cell line is shown in Fig. 2. A $\geq 10$-fold difference in cell kill was observed between clones derived from each parental cell line. In addition, a more than 2-log difference in the sensitivity of individual clones was observed between cell lines. In all cases and consistent with the adenovirus experiments, SW620 cells expressing HSV-TK were more sensitive to low concentrations of ganciclovir compared with HT-29 cells. In each cell line, the clones exhibiting the largest difference in sensitivity to GCV were chosen for further characterization. HT-29 clone 4 and SW620 clone 2 exhibited both lower HSV-TK expression and activity compared with HT-29 clone 8 and SW620 clone 3, respectively. Growth rates of individual clones were similar with doubling times of $20 \mathrm{hr}$ (clone 2), $23 \mathrm{hr}$ (clones 3 and 4), and $24 \mathrm{hr}$ (clone 8). Increased sensitivity to GCV correlated with the higher HSV-TK expression as determined by Northem analysis (Fig. 3) and HSV-TK activity measured in cell lysates (data not shown; and Shewach et al., 1994b). These stably transduced clonal cell lines vary in their response to ganciclovir, enabling a comparison between cytotoxicity and the effects of HSV-TK expression and ganciclovir metabolism.

\section{Measurement of GCV nucleotides in HSV-TK-expressing cells}

Since GCV triphosphate is the presumed cytotoxic metabolite of ganciclovir, clonal cell lines were first characterized for their ability to phosphorylate GCV. In all cell lines expressing HSV-TK, ganciclovir was preferentially phosphorylated to its triphosphate derivative. Ganciclovir triphosphate accounted for the majority $(70-80 \%)$ of the total radioactivity measured in cell lysates, with GCV mono- and diphosphate levels approximately 5 and 20\%, respectively. As shown in Fig. 4, HT-29 and SW620 cells differed in their ability to accumulate GCV triphosphate during a 24-hr exposure to $1 \mu M$ ganciclovir. Compared with HT-29 cells, SW620 cells displayed a more rapid accumulation of GCV triphosphate during the initial 8-hr exposure to drug. Accumulation of GCV triphosphate appeared to plateau after $8 \mathrm{hr}$ for SW620 clones and after $12 \mathrm{hr}$ for HT29 clones. A twofold difference in GCV triphosphate accumulation was observed between low and high HSV-TK-express- 
A

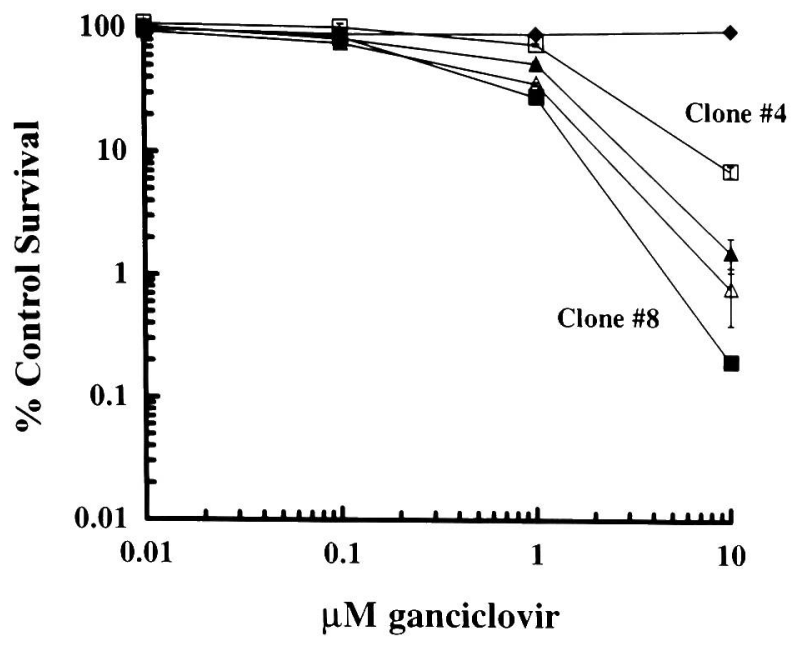

B

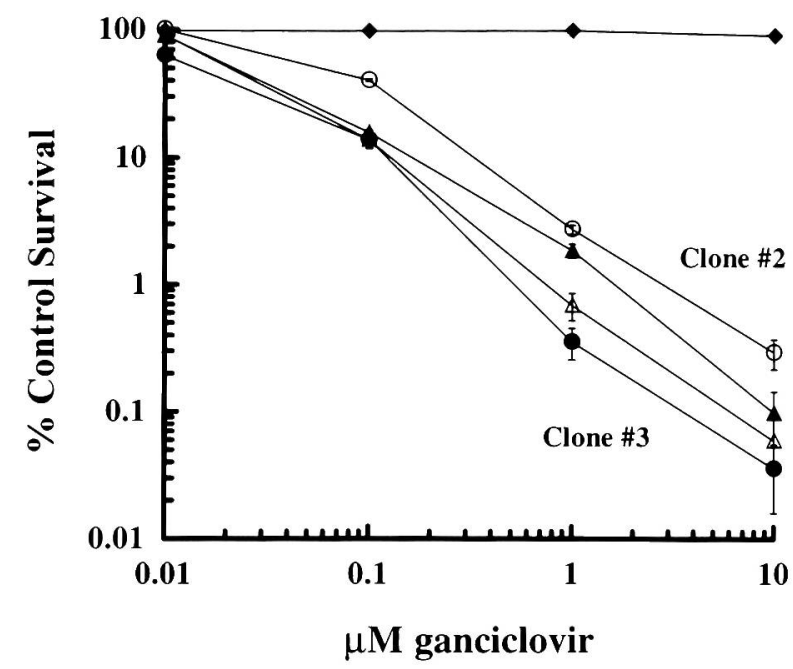

FIG. 2. GCV sensitivity of clonal HT-29 (A) and SW620 (B) cell lines stably expressing HSV-TK. Four (from a total of 10) monoclonal populations representing the range of GCV sensitivity are shown here. Cells were selected after transduction with a retrovirus containing the cDNA for HSV-TK. Clonogenic cell survival was determined after a 24-hr incubation with GCV. HT-29 clones 4 (open squares) and 8 (solid squares) and SW620 clones 2 (open circles) and 3 (solid circles) were chosen for subsequent study because they represent the low and high extremes of GCV cytotoxicity. Triangles indicate clones with intermediate sensitivies to GCV. Control cells (diamonds) are a stable cell line expressing $\beta$-galactosidase instead of HSVTK. Data are reported as the mean $\pm \operatorname{SEM}(n \geq 3)$.

ing clones from the same cell line after the first 4 hr of drug exposure. This 2-fold difference in the level of GCV triphosphate corresponded to a 10-fold difference in cell death (Fig. 2). However, somewhat higher GCV triphosphate levels were observed in HT-29 clone 8 compared with the two more sensitive SW620 clones. After $12 \mathrm{hr}$ of drug exposure, these cell lines also differed in their ability to retain GCV triphosphate.

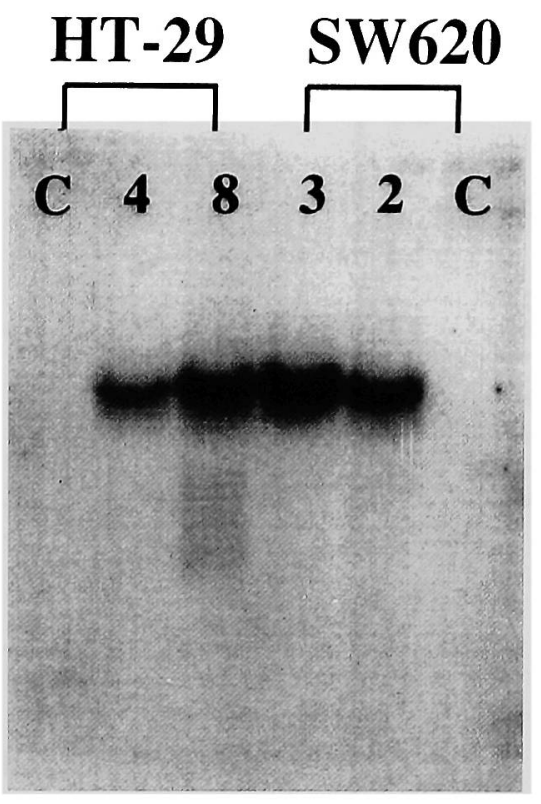

FIG. 3. Northern blot analysis of HSV-TK mRNA levels in HT-29 and SW620 monoclonal populations stably expressing HSV-TK. Twenty micrograms of total RNA from each clone was separated on a $1 \%$ agarose gel, transferred to a nylon membrane, and hybridized to a ${ }^{32} \mathrm{P}$-radiolabeled HSV-TK cDNA probe. Northern blot autoradiograms of the more (HT-29 clone 8 and SW6290 clone 3) and less (HT-29 clone 4 and SW620 clone 2) GCV-sensitive clones are presented. Lanes indicated with a $C$ represent total RNA from monoclones stably expressing LacZ. An equal amount of total RNA was loaded per well, on the basis of a comparison of $28 \mathrm{~S}$ and $18 \mathrm{~S}$ ribosomal RNA bands stained with ethidium bromide (data not shown).

In Fig. 5, the initial half-life of GCV triphosphate was determined to be 5.5 and $3.5 \mathrm{hr}$ for HT-29 and SW620 cell lines, respectively. Half-lives for high- and low-expressing HSV-TK clones were similar. These results demonstrate that between the two clones of each subline, GCV sensitivity corresponded with higher accumulation of GCV triphosphate, while retention, based on the intracellular half-life of GCV triphosphate, was relatively short and similar between clones.

\section{Measurement of the level of GCV monophosphate incorporation in DNA}

Since incorporation of GCV monophosphate in DNA is thought to be important for cytotoxicity, the level of DNA incorporation was measured in the HSV-TK-expressing cell lines. In SW620 cells, radiolabeled GCV in nucleic acid was associated exclusively with DNA (data not shown). The amount of GCV monophosphate incorporated in DNA in both HT-29 and SW620 cells was measured and compared in Fig. 6. GCV monophosphate incorporation increased continuously over the 24-hr incubation with $1 \mu M \mathrm{GCV}$ in all cell lines and represented approximately 2 to $8 \%$ of the GCV triphosphate pools (Fig. 4). Again, a less than 2-fold difference between high (clones 8 and 3) and low (clones 4 and 2) HSV-TK-expressing clones corresponded to a 10 -fold difference in cell survival. In addition, the amount of GCV monophosphate in DNA corresponded to the relative sensitivity of the four cell lines. As il- 


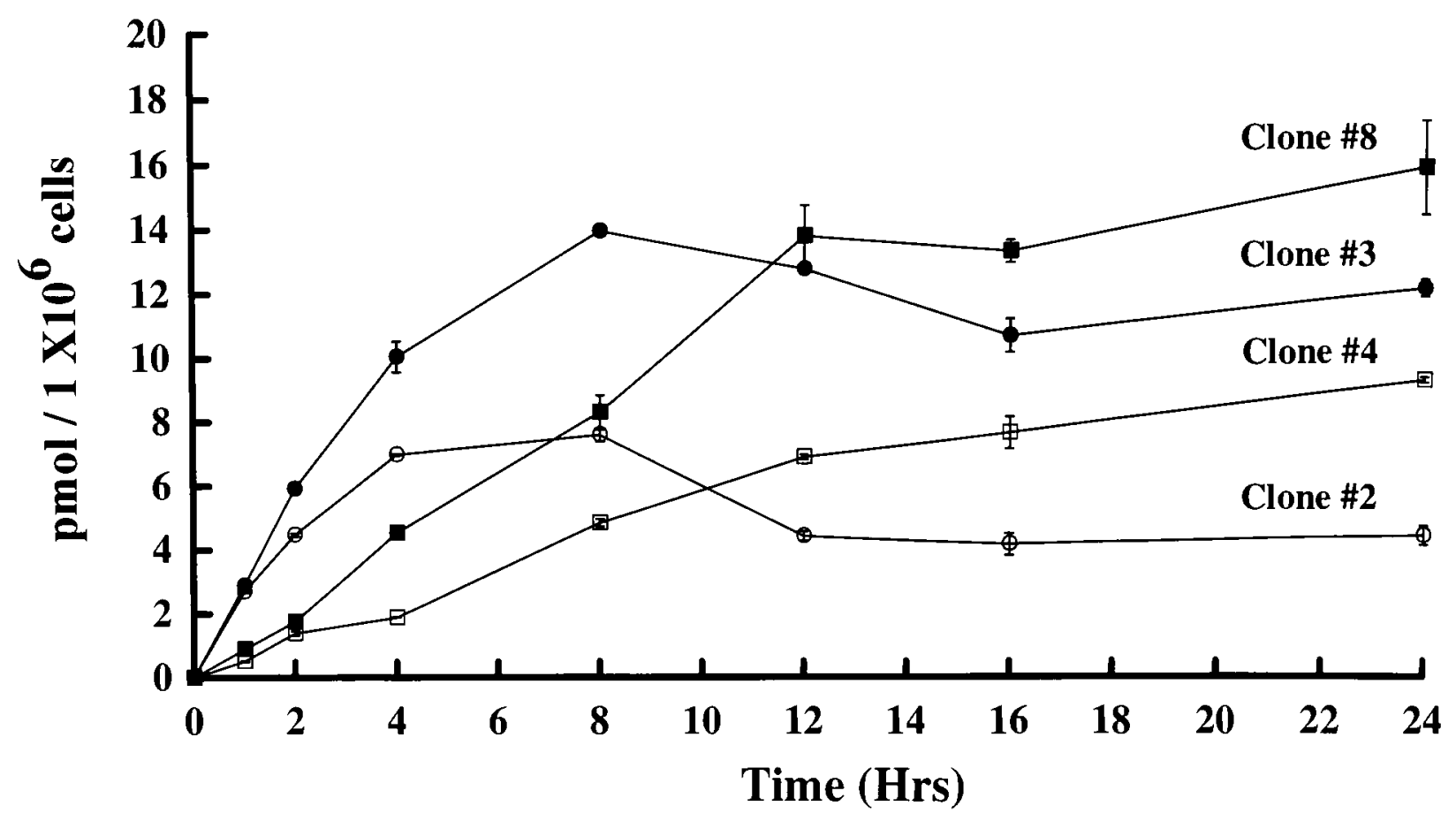

FIG. 4. Accumulation of $\left[{ }^{3} \mathrm{H}\right] \mathrm{GCV}$ triphosphate in HT-29 (squares) and SW620 (circles) low (open symbols) and high (solid symbols) HSV-TK-expressing clones. Exponentially growing cells were harvested at the indicated time points following the addition of $1 \mu M$ GCV (containing approximately $10 \%\left[{ }^{3} \mathrm{H}\right] \mathrm{GCV}$ ) and nucleotides were analyzed by HPLC. Results are the average \pm SEM from two experiments.

lustrated in Fig. 7, the level of GCV monophosphate in DNA continued to increase even after removal of exogenous drug and plateaued after 8 to $12 \mathrm{hr}$. These data suggest that, following incorporation into the DNA, GCV monophosphate is resistant to excision.

\section{Analysis of bystander killing in HT-29 and SW620 cells}

Significant bystander cytotoxicity was indicated for both HT29 and SW620 cells on the basis of the multilog kill observed with low levels of adenoviral transduction. Bystander killing was investigated further in experiments in which stably expressing HSV-TK cells were mixed with cells stably expressing LacZ. Following a 24-hr exposure to GCV, the survival of LacZ-expressing bystander cells was measured using a chromogenic assay. Bystander cell killing was compared using either two different ratios of HSV-TK- versus LacZ-expressing cells or two different cell densities (Fig. 8). In all cases tested, SW620 cells (Fig. 8B) displayed greater bystander killing than HT-29 cells (Fig. 8A). The growth rates of HSV-TK- and LacZexpressing clones were similar, and the proportion of HSV-TK relative to LacZ cells (determined by X-Gal staining) at the conclusion of the drug incubation period was similar to that in the initial culture setup. Bystander killing increased with higher HSV-TK expression and greater number of HSV-TK-expressing cells in both cell lines. The level of confluency also appeared to be an important determinant of bystander killing since more SW620 bystander cells were killed with $10 \mu M \mathrm{GCV}$ in mixtures of $25 \%$ HSV-TK-expressing cells at high density compared with low-density populations of $50 \%$ HSV-TK expressers
(Fig. 8B). To determine whether bystander killing may be mediated by gap junctional intercellular communication (GJIC), the level of GJIC in both HT-29 and SW620 cells was determined by the frequency of fluorescent dye transfer from individual cells microinjected with Lucifer Yellow $\mathrm{CH}$ (Ren et al., 1994). Microinjected, dye-loaded HT-29 cells were capable of transferring dye to more than $50 \%$ of surrounding cells. In contrast, SW620 cells transferred dye to fewer than $3 \%$ of neighboring cells. This demonstrates that as many as $95 \%$ of the bystander SW620 cells can be killed (Fig. 8B) even in the absence of significant GJIC.

\section{The extent of GCV triphosphate transfer between} HSV-TK-expressing and bystander cells

Since transfer of GCV nucleotides has been postulated as the mechanism for bystander cell killing with GCV, it was of interest to determine whether this occurred in our system. Our initial approach to determine whether GCV triphosphate was transferred between HSV-TK-expressing cells and nonexpressing bystander cells was to measure GCV nucleotide levels in mixed cultures containing equal numbers of each cell type. If no transfer occurred, then the amount of radiolabeled nucleotides and DNA should be proportional to the amounts observed in cultures of $100 \%$ HSV-TK cells. During a $24-\mathrm{hr}$ exposure to $1 \mu M \mathrm{GCV}$ (Table 1), almost twice as much GCV triphosphate as expected was present for both cell lines and as much as three times the expected levels in the DNA. These data suggest but do not prove that GCV nucleotides are transferred from HSV-TK-expressing to nonexpressing cells.

To determine conclusively whether GCV nucleotides are 


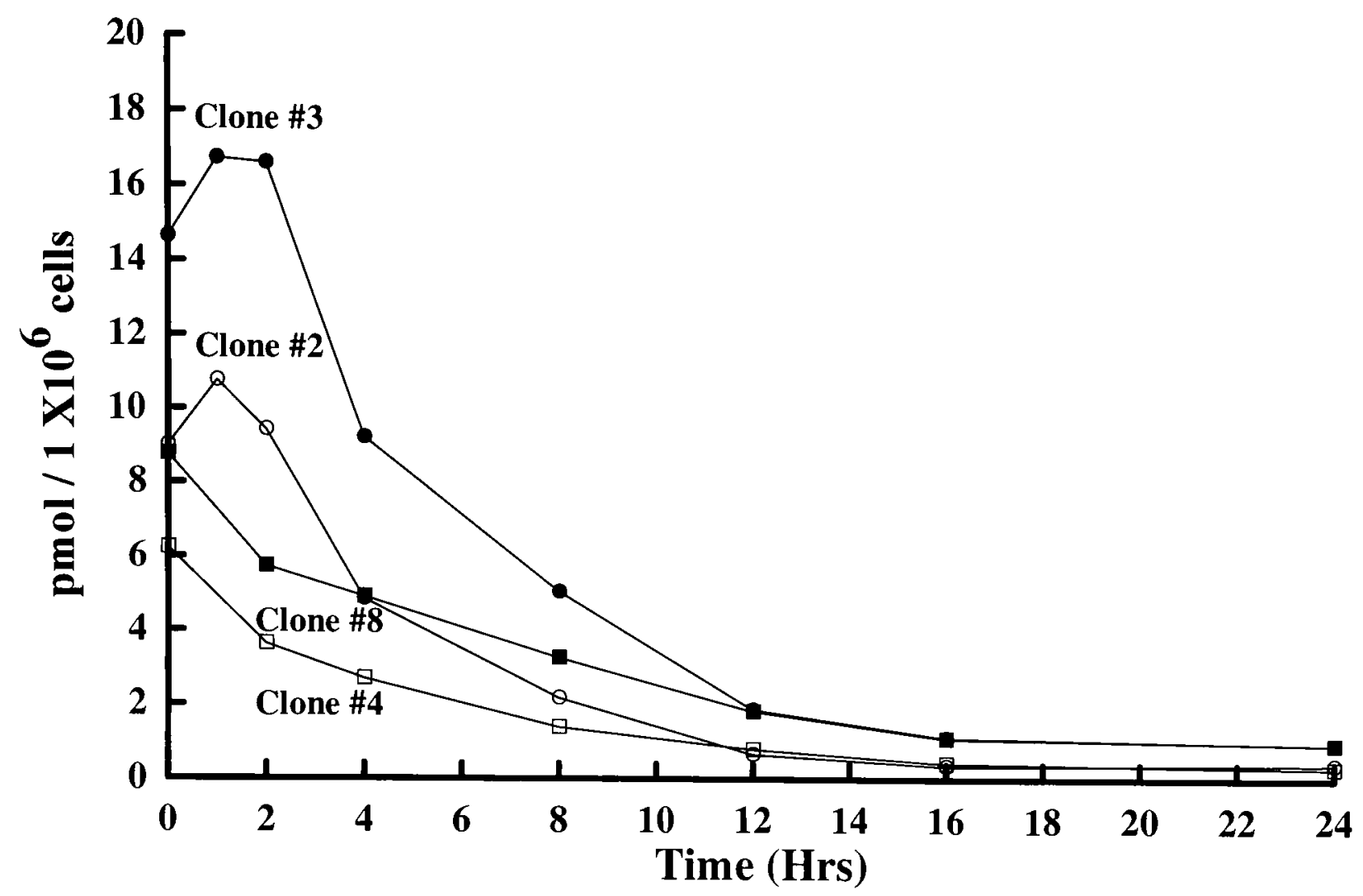

FIG. 5. Retention of GCV triphosphate in HT-29 (squares) and SW620 (circles) HSV-TK-expressing clones. Exponentially growing cells were incubated with $1 \mu M \mathrm{GCV}$ (containing approximately $10 \%\left[{ }^{3} \mathrm{H}\right] \mathrm{GCV}$ ) for $4 \mathrm{hr}$ (SW620) or $8 \mathrm{hr}$ (HT-29), followed by replacement of fresh growth medium (time, $0 \mathrm{hr}$ ). A longer incubation time was necessary for HT-29 cells to allow sufficient GCV triphosphate for detection in the absence of exogenous drug. Eight-hour GCV triphosphate levels in HT-29 clones were more similar to GCV triphosphate accumulation after $4 \mathrm{hr}$ in SW620 clones (see Fig. 4). Nucleotides were extracted from cells and analyzed by HPLC. Data are from a single representative experiment.

transferred to bystander cells, we developed an assay to physically separate HSV-TK- and non-HSV-TK-expressing cells. This separation allowed us to directly quantitate the levels of GCV nucleotides in each population individually. In these experiments, bystander cells are represented by a monoclonal SW620 cell line stably transfected with a pHook vector. pHookexpressing cells produce a surface antibody that binds to hapten-coated magnetic beads, enabling us to separate these (bystander) cells from cocultures using a magnetic apparatus. Cocultures consisting of 50:50 mixtures of HSV-TK- and pHook-expressing cells were subjected to separation using this pHook magnetic system. After extensive washing, the adherent cells accounted for $10-15 \%$ of the total cells. To verify the purity of this population, three control experiments were performed. After separation, cells were plated and examined visually for the presence of magnetic beads. Ninety-nine percent of the isolated cells had at least one attached hapten bead. Cocultures of 50:50 mixtures of pHook- and LacZ-expressing cells were grown, separated with the magnetic apparatus, plated, and subjected to a chromogenic assay. The number of blue-stained cells were counted and the level of contaminating LacZ cells was determined to be approximately $3 \%$. For the final control, we incubated $100 \%$ HSV-TK-expressing cells (clone 3 ) with 1 $\mu M\left[{ }^{3} \mathrm{H}\right] \mathrm{GCV}$ for $24 \mathrm{hr}$. These cells were then harvested and mixed with an equal number of pHook cells and immediately separated with a magnet. [Radiolabeled GCV derivatives were not detected in the separated cells in which only background counts were observed compared with more than $1 \times 10^{5} \mathrm{cpm}$ of $\left[{ }^{3} \mathrm{H}\right] \mathrm{GCV}$ triphosphate detected in the initial clone 3 cells.] These studies demonstrate that this technique was able to separate pHook-expressing from HSV-TK-expressing cells with $\geq 97 \%$ purity, and there was no artifactual carryover of radioactivity from the HSV-TK- to pHook-expressing cells.

Table 2 shows the level of radiolabeled GCV triphosphate measured in bystander cells during a 24-hour incubation with $1 \mu M \mathrm{GCV}$. Beginning at $4 \mathrm{hr}$ a significant transfer of phosphorylated GCV was observed. These data demonstrate that GCV triphosphate accumulated continuously in both bystander and HSV-TK-expressing cells throughout the incubation period, under both the low- and high-density conditions. Levels of GCV triphosphate in bystander cells increased with higher cell density, consistent with the greater toxicity to bystander cells at high density (Fig. 8B). Interestingly, the increase in GCV triphosphate with time in bystander cells grown at high density paralleled that in the HSV-TK/bystander cell mixtures, whereas smaller changes in GCV triphosphate were observed in bystander cells cultured at low density. These data demonstrate conclusively that GCV nucleotides can be transferred from HSV-TK-expressing to nonexpressing cells in cocultures, even in a cell line that exhibits low GJIC. 


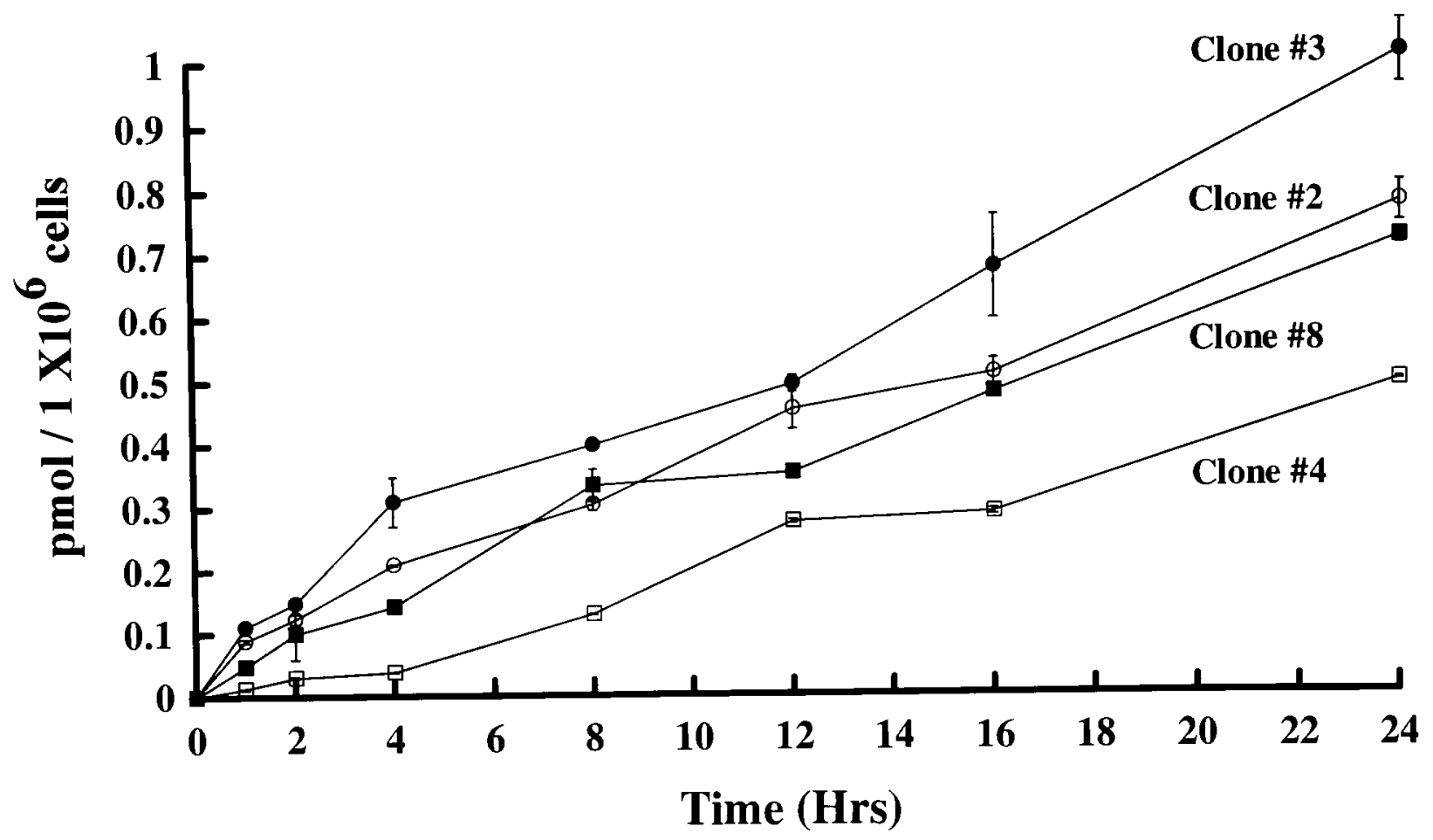

FIG. 6. Incorporation of $\left[{ }^{3} \mathrm{H}\right] \mathrm{GCV}$ monophosphate into DNA. The level of GCV monophosphate in DNA from HT-29 (squares) and SW620 (circles) low and high HSV-TK-expressing clones described in Fig. 4 was determined over a 24-hr time period following addition of $1 \mu M \mathrm{GCV}$ (containing approximately $10 \%\left[{ }^{3} \mathrm{H}\right] \mathrm{GCV}$ ). Nucleic acids were precipitated with perchloric acid and quantitated by liquid scintillation spectrometry.

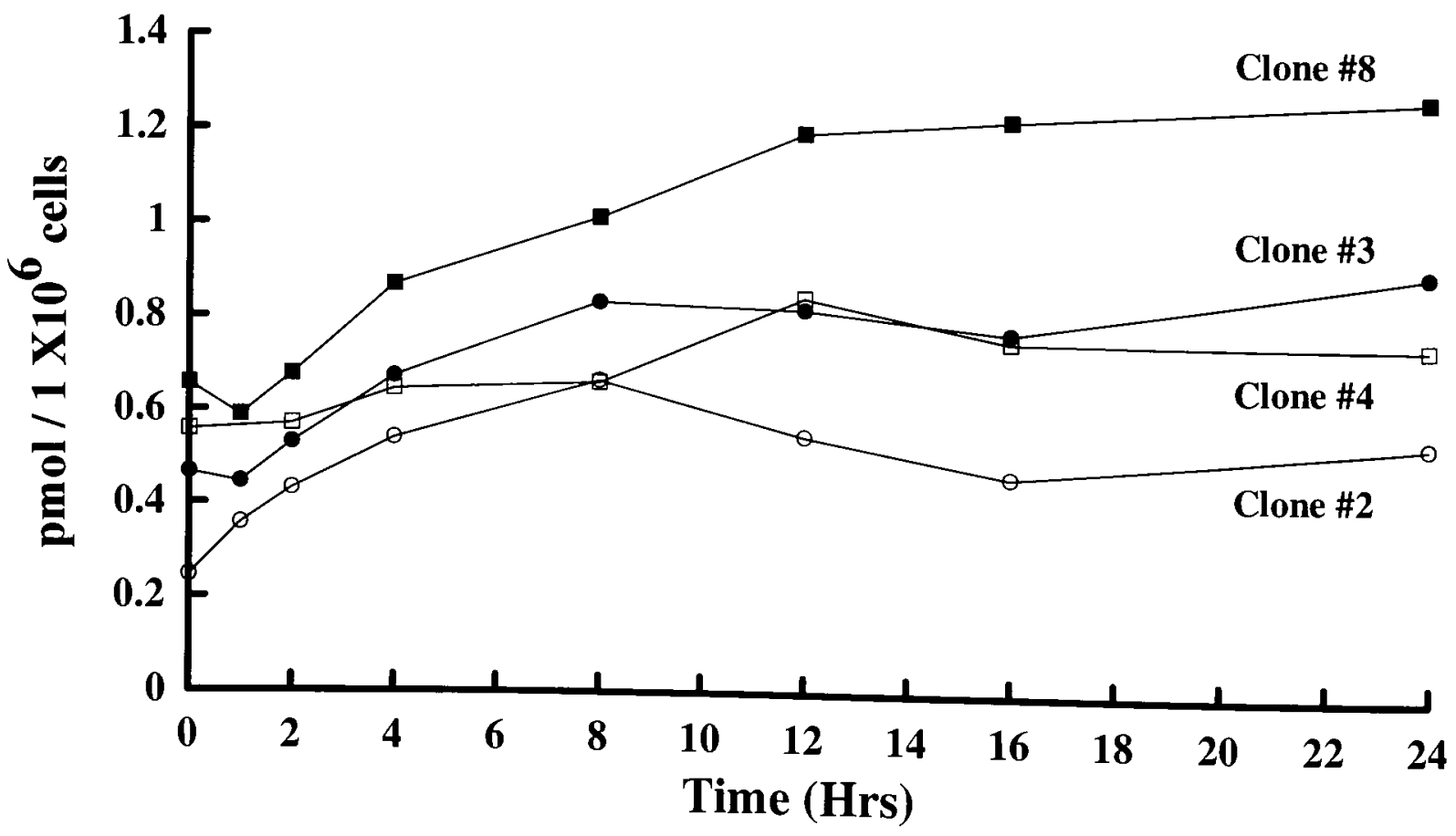

FIG. 7. Incorporation of $\left[{ }^{3} \mathrm{H}\right] \mathrm{GCV}$ monophosphate into DNA following removal of drug HT-29 and SW620 cells were treated with $1 \mu M \mathrm{GCV}$ (containing approximately $10 \%\left[{ }^{3} \mathrm{H}\right] \mathrm{GCV}$ ) for 8 and $4 \mathrm{hr}$, respectively, before drug removal and samples were collected over a 24-hr time course. The amount of tritium in acid-insoluble nucleic acids from HT-29 (squares) and SW620 (circles) low and high HSV-TK-expressing clones (Fig. 5) were quantitated by liquid scintillation spectrometry. 
A
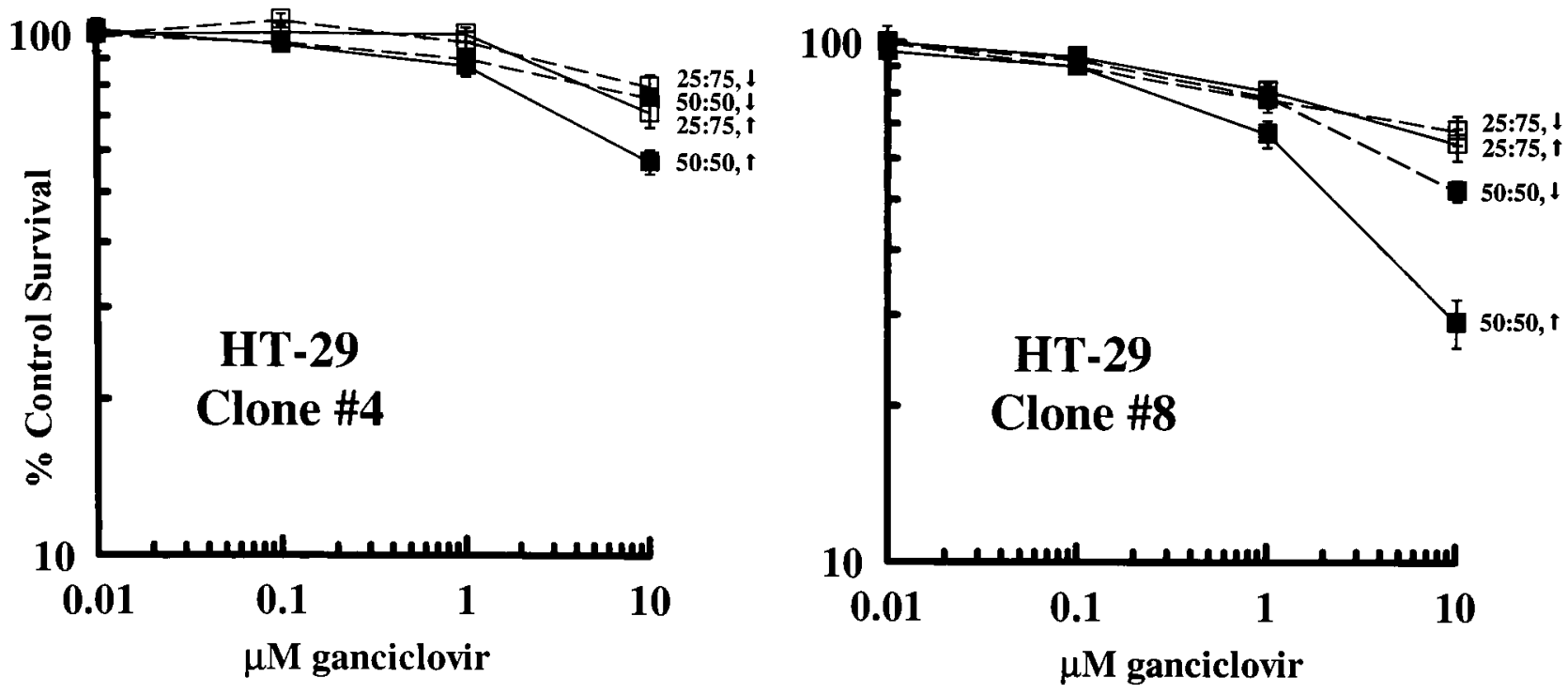

B
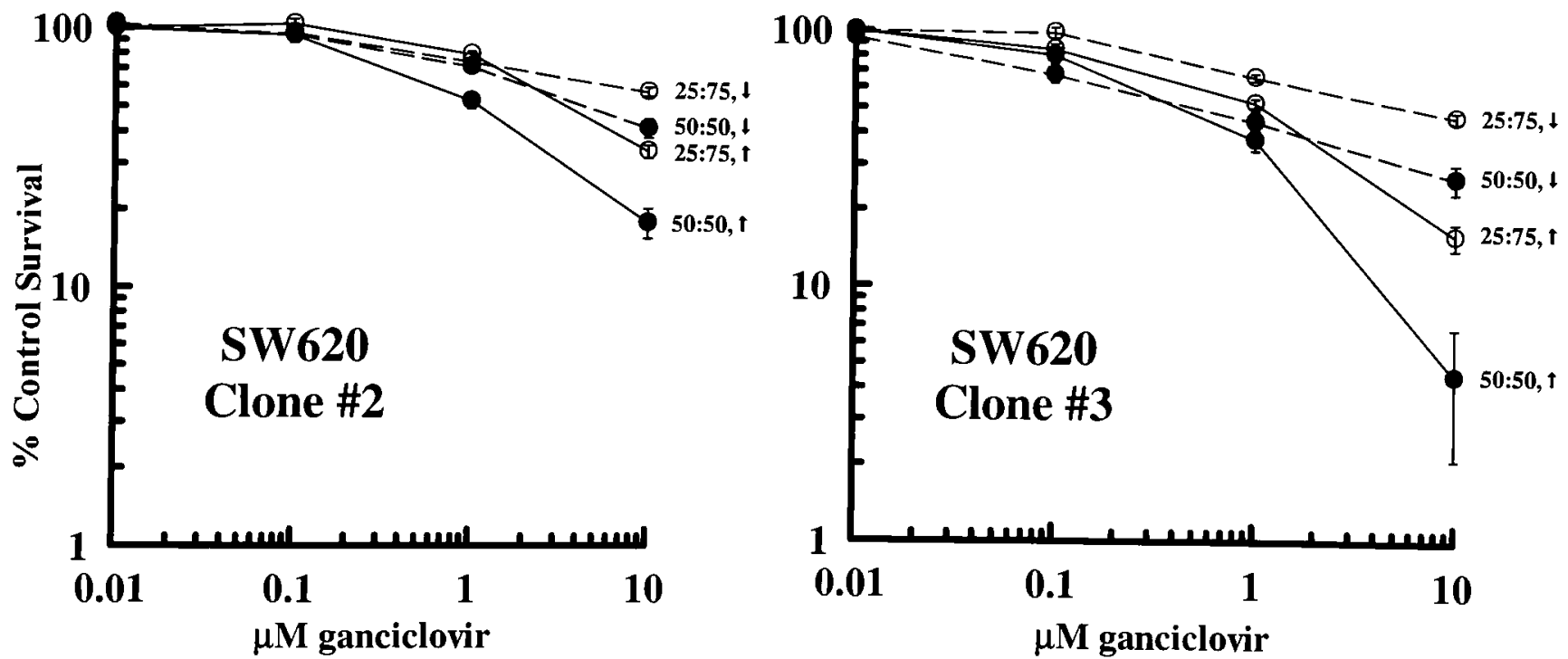

FIG. 8. Effect of cell density and number of HSV-TK-expressing cells on the sensitivity of HT-29 (A) and SW620 (B) clones. Low HSV-TK-expressing clones are represented on the left, high expressers on the right. HSV-TK-expressing clones were cocultured with $\beta$-galactosidase-expressing cells at either low (dashed lines, $\downarrow$ ) or high densities (solid lines, $\uparrow$ ) and at an HSVTK-to-LacZ clone ratio of 50:50 (solid symbols) or 25:75 (open symbols). Low-density cultures contained $2.5-3.5 \times 10^{6}$ cells $/ 25$ $\mathrm{cm}^{2}$ flask for HT-29 cells and $4-5 \times 10^{6}$ cells $/ 25-\mathrm{cm}^{2}$ flask for SW620 cells. High-density cultures contained $4.5-5.5 \times 10^{6}$ cells $/ 25-\mathrm{cm}^{2}$ flask and $8-9 \times 10^{6}$ cells $/ 25-\mathrm{cm}^{2}$ flask for HT-29 and SW620 cells, respectively. Clonal cell survival of LacZ-expressing cells was determined by a chromogenic assay following a 24 -hr incubation with GCV. Each point represents the mean \pm SEM from at least six determinations. 
Table 1. InCreased Recovery of $\left[{ }^{3} \mathrm{H}\right]$ GCV in Mixtures of Bystander Cultures ${ }^{a}$

\begin{tabular}{|c|c|c|c|c|c|}
\hline \multirow[b]{3}{*}{ Cell type } & \multirow{3}{*}{$\begin{array}{c}H S V-T K: L a c Z \\
\text { ratio }\end{array}$} & \multicolumn{4}{|c|}{$\left[{ }^{3} \mathrm{H}\right] G \mathrm{CV}\left(\mathrm{pmol} / 10^{6}\right.$ cells) incorporated into: } \\
\hline & & \multicolumn{2}{|c|}{ Triphosphate } & \multicolumn{2}{|c|}{ DNA } \\
\hline & & Observed & Expected & Observed & Expected \\
\hline \multirow[t]{3}{*}{ HT-29 } & $100: 0$ & 8.19 & 8.19 & 1.31 & 1.31 \\
\hline & $50: 50$ & $5.50(67 \%)$ & 4.10 & $1.23(94 \%)$ & 0.66 \\
\hline & $25: 75$ & $3.66(45 \%)$ & 2.05 & $1.06(81 \%)$ & 0.33 \\
\hline \multirow[t]{3}{*}{ SW620 } & $100: 0$ & 9.73 & 9.73 & 1.52 & 1.52 \\
\hline & $50: 50$ & $6.36(65 \%)$ & 4.87 & $1.32(87 \%)$ & 0.76 \\
\hline & $25: 75$ & $3.99(41 \%)$ & 2.43 & $0.96(63 \%)$ & 0.38 \\
\hline
\end{tabular}

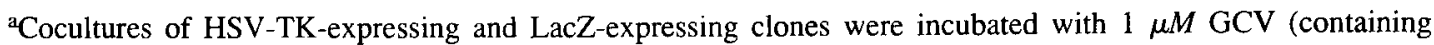
approximately $10 \%\left[{ }^{3} \mathrm{H}\right] \mathrm{GCV}$ ) for $24 \mathrm{hr}$. Cells were then harvested and the level of GCV triphosphate was measured by HPLC analysis. The amount of $\left[{ }^{3} \mathrm{H}\right] \mathrm{GCV}$ monophosphate in DNA was measured in the acidinsoluble cell extract. Data are from a representative experiment with cells treated at low density. The numbers in parentheses represent the percentage relative to cultures of $100 \%$ HSV-TK-expressing cells.

\section{DISCUSSION}

Many studies in the literature have demonstrated the excellent antitumor activity in vitro and in vivo of $\mathrm{GCV}$ in tumor cells engineered to express HSV-TK (Wu et al., 1994; Eastham et al., 1996; Kaneko et al., 1996; Vincent et al., 1996). However, few reports describe the biochemical mechanism by which GCV elicits potent antitumor effects. In this study, we have evaluated the metabolism of GCV and its mechanism of cytotoxic action in both primary (HT-29) and metastatic (SW620) human colon carcinoma cell lines. Our results demonstrate that GCV induced a multilog cell kill in both colon cancer cell lines expressing HSV-TK. Furthermore, both cell lines exhibited substantial killing of bystander cells cocultured with HSV-TK-expressing cells, even in the absence of high levels of GJIC. We investigated several possible explanations for the increased GCV cytotoxicity in SW620 cells, including differences in (1) GCV triphosphate accumulation, (2) GCV triphosphate retention, (3) incorporation of GCV into DNA, and (4) bystander killing.

Our group has previously demonstrated that increased expression of HSV-TK through transduction with increasing amounts of adenovirus resulted in greater cytotoxicity in cultured rat glioma cells (Shewach et al., 1994b). However, these results were complicated by toxicity from the adenovirus vector alone. Here we have transduced two colon carcinoma cell lines with a retrovirus vector encoding the cDNA for HSV-TK and developed from each parental cell type more than 10 clonal sublines that stably expressed the viral kinase. This system allowed us to determine the effect of increasing HSV-TK expression on GCV sensitivity without the complication of adenovirus toxicity. The results demonstrated that these sublines varied in their level of expression of HSV-TK, which resulted in as much as a 10 -fold difference in sensitivity to GCV. Overall, the HT-29 sublines were less sensitive than the SW620 cells to GCV. However, GCV was highly cytotoxic to both cell lines, in which a concentration of $10 \mu M$ effected more than a 2- to $3-\log$ decrease in cell survival in the HT-29 and SW620 cell lines, respectively, following a 24-hr incubation.

As hypothesized, greater sensitivity to GCV was associated with higher levels of GCV nucleotides and incorporation into DNA. However, an unexpected result from these studies was that the level of GCV triphosphate that accumulated under conditions that induced more than a $2-\log$ reduction in cell survival

Table 2. TRansfer of $\left[{ }^{3} \mathrm{H}\right]$ GCV Nucleotides BetweEn HSV-TK-ExPREsSing AND Bystander Cultures ${ }^{a}$

\begin{tabular}{lcccc}
\hline & \multicolumn{4}{c}{$\left.I^{3} H\right] G C V$ triphosphate $\left(p m o l / 10^{6}\right.$ cells $)$} \\
\cline { 2 - 5 } Time & \multicolumn{2}{c}{ High density } & \multicolumn{2}{c}{ Low density } \\
\cline { 2 - 5 } & Total & Bystander & Total & Bystander \\
\hline 2 & $3.10 \pm 0.59$ & $3.39 \pm 0.55$ & $6.72 \pm 1.92$ & $0.55 \pm 0.07$ \\
4 & $7.41 \pm 0.35$ & $9.27 \pm 0.94$ & $10.23 \pm 2.26$ & $1.04 \pm 0.11$ \\
8 & $15.37 \pm 0.69$ & $14.27 \pm 0.73$ & $14.68 \pm 1.07$ & $3.97 \pm 0.49$ \\
24 & $21.01 \pm 1.90$ & &
\end{tabular}

aSW620 cocultures $(50: 50)$ of HSV-TK- and pHook-expressing clones were incubated with $1 \mu M \mathrm{GCV}$ (containing approximately $10 \%\left[{ }^{3} \mathrm{H}\right] \mathrm{GCV}$ ) for the indicated times. Bystander cells were physically separated from HSV-TK-expressing cells with a magnet. Values represent the mean \pm SEM from two separate experiments.

Abbreviations: Not det., not detectable; n.d., not determined. 
was relatively low compared with levels of other antimetabolites in these cell types (Shewach et al., 1994a). As illustrated in Fig. 4. accumulation of less than 20 pmol of GCV triphosphate per $10^{6}$ cells was sufficient to effect more than a 3-log decrease in cell survival. Thus, GCV triphosphate induced high cytotoxicity at intracellular concentrations that were comparable to endogenous deoxynucleotides in the colon carcinoma cell lines. In comparison, the antitumor nucleoside analog difluorodeoxycytidine, which also interferes with DNA synthesis as a triphosphate, induced only a $1.5-\log$ cell kill in HT-29 cells at nucleotide concentrations more than 100 times higher than those of GCV (Shewach et al., 1994a). Furthermore, differences of approximately 2-fold in GCV triphosphate levels and incorporation into DNA corresponded to a 10 -fold difference in cytotoxicity. These results demonstrate that GCV triphosphate is a highly potent cytotoxic nucleotide in these colon carcinoma cell lines. In our experience with nucleoside analogs that interfere with DNA synthesis, this level of cytotoxicity from a nucleotide analog is highly unusual, and the mechanism by which GCV interacts so potently with DNA synthesis merits investigation.

When comparing the sublines of HT-29 and SW620 cells, increased sensitivity to GCV corresponded to higher levels of GCV triphosphate and incorporation into DNA. However, the more sensitive HT-29 clone 8 accumulated higher levels of GCV triphosphate after $12 \mathrm{hr}$ of drug exposure and was 10 -fold less sensitive to GCV compared with the more sensitive SW620 clone 3 . In addition, retention of GCV triphosphate was slightly longer for the less sensitive HT-29 sublines. These apparent contradictions may be understood by evaluation of the amount of GCV monophosphate in DNA. In a comparison of the four clonal lines, greater sensitivity to GCV corresponded to higher levels of GCV monophosphate incorporated into DNA (Fig. 6). Taken together, these data suggest that incorporation of GCV monophosphate into DNA is the factor most predictive of cytotoxicity, and that relatively modest increments in DNA incorporation result in larger differences in cell survival.

The data demonstrated that, for all four clonal lines, GCV monophosphate was well retained once incorporated into DNA. These data are consistent with reports on the stability of GCV monophosphate in DNA and on the difficulty in excising it (Reardon, 1989; Marshalko et al., 1995). Interestingly, the amount of GCV nucleotide in DNA increased for at least the first $8 \mathrm{hr}$ following drug washout (Fig. 7), despite the fact that the precursor, GCV triphosphate, was decreasing with a halflife between 3 and $5 \mathrm{hr}$. These data combined with the observation that at least $8 \%$ of the GCV nucleotide pool appeared in DNA suggest that GCV triphosphate is readily incorporated into DNA. This is consistent with reports of low $K_{\mathrm{m}}$ values for GCV triphosphate with mammalian DNA polymerases (Reid et al., 1988; Reardon, 1989; Ilsley et al., 1995).

The ability of GCV to kill neighboring cells that do not express HSV-TK is an important feature of antitumor activity in vivo. Here we have demonstrated that bystander killing is dependent on the level of HSV-TK expression, the number of cells expressing the viral kinase, and the cell density in both the HT29 and SW620 cell lines. Paralleling the results in populations of cells all of which express HSV-TK, the SW620 bystander cells were more sensitive to killing compared with HT-29 bystander cells when cocultured with HSV-TK-expressing cells.

Other groups have suggested that bystander killing with GCV is mediated by the transfer of GCV nucleotides from HSV-TKexpressing to nonexpressing cells. $\mathrm{Bi}$ and Stambrook initially demonstrated the presence of radioactivity in bystander cells cocultured with HSV-TK-expressing cells and tritiated GCV, although there was no positive identification of the chemical nature of the radioactive material retained in bystander cells $(\mathrm{Bi}$ et al., 1993). Another group demonstrated the transfer of dye between cells in coculture, suggesting that soluble metabolites such as GCV nucleotides could also be transferred in this manner (Freeman et al., 1993). One report identified transfer of phosphorylated GCV in cocultures of HSV-TK-expressing human and wild-type rodent cell lines (Ishii-Morita et al., 1997). Similar to the results presented here, low levels of GCV metabolites were observed in both HSV-TK-expressing and wild-type bystander cells. However, these studies were limited to a single 24-hr time point, using one concentration of GCV with equal amounts of HSV-TK-expressing and xenogeneic bystander cells. In addition, the authors identified both bystander-sensitive and -resistant tumor cells and suggested metabolic cooperation as a mechanism of transfer but did not examine the level of GJIC in these cell lines. Here we have performed a more extensive study of transfer of phosphorylated GCV between HSVTK and bystander cells derived from the same parental line. Utilizing the pHook methodology, we have quantitated the transfer of GCV nucleotide into the bystander cells in the SW620 cell line. This transfer occurred within $4 \mathrm{hr}$, increasing with the length of incubation and the density of the cell culture. Although we could not produce sufficient pHook expression in HT-29 cells to isolate the bystander cells from coculture and analyze nucleotide pools, dilution studies using cocultures of HT-29 cells expressing HSV-TK and LacZ bystander cells suggest that a similar transfer of GCV nucleotides occurs in these cells as well. Furthermore, these studies demonstrate that this transfer can occur in a cell line with minimal gap junctional intercellular communication.

Two theories have been reported to explain the hypothesized transfer of GCV nucleotides to neighboring non-HSV-TK-expressing tumor cells in vitro following GCV treatment. One proposed mechanism hypothesizes that HSV-TK-expressing cells undergoing apoptosis develop apoptotic vesicles that may contain GCV nucleotides, which are subsequently phagocytosed by non-HSV-TK-expressing cells (Freeman et al., 1993; Samejima and Meruelo, 1995). We do not believe this to be a prominent mechanism in HT-29 and SW620 cells because we were unable to identify apoptotic vesicles visually during the course of our experiments. Furthermore, transfer of GCV was demonstrated to occur within $4 \mathrm{hr}$ after GCV addition to the coculture, which is sooner than apoptosis would likely occur in competent cell types.

A second theory suggests that the bystander effect is mediated by the transfer of GCV nucleotides through gap junctional channels (Bi et al., 1993; Pitts, 1994). Gap junctions are plasma membrane channels that link adjacent cells and permit the passage of small (<1000 Da) molecules (reviewed in Ruch, 1994; Yeager and Nicholson, 1996). These channels are formed by two connecting hemichannels (connexons), one from each neighboring cell, that are composed themselves of six protein subunits (connexins, $\mathrm{Cx}$ ). Several studies have demonstrated a strong correlation between bystander killing and the level of GJIC (Fick et al., 1995; Mesnil et al., 1996). Indeed, the by- 
stander killing in the HT-29 cell line may be mediated by the relatively high level of GJC that we measured. Unexpectedly, the SW620 cell line exhibited superior bystander killing despite a low level of GJC ( $\leq 3 \%)$. While it is still possible that the low level of GJC in this cell line is completely responsible for the transfer of cytotoxic GCV nucleotides, it appears unlikely given the rapid rate of transfer of these metabolites into neighboring cells. Other investigators have also reported that SW620 cells are a poorly communicating cell line although they express connexin 32 (Cx32) mRNA and protein (Mesnil et al., 1993). We observed that our SW620 and HT-29 clones expressed Cx32 mRNA at similar levels, but that the localization of the protein was different between the cell lines. Immunofluorescence staining indicated that $\mathrm{Cx} 32$ was spread diffusely over the surface of SW620 cells whereas the protein was more localized in discrete plaques between adjacent HT-29 cells (data not shown). This suggests that Cx32 is expressed in SW620 cells but does not readily form gap junctional plaques and functional intercellular channels, resulting in low GJIC.

In view of the absence of apoptotic vesicle formation and low GJIC, the mechanism that allows the passage of phosphorylated GCV from HSV-TK-expressing to nonexpressing SW620 cells is not clear. With 3\% or fewer of the SW620 cells able to transfer Lucifer Yellow dye to neighboring cells, it seems possible but not probable that this accounts for GCV nucleotide transfer. In particular, the fact that the SW620 cells transferred at least as high a percentage of GCV nucleotides as the HT-29 cells, in which 10 times as many cells exhibited GJC, renders it unlikely that the low GJIC in SW620 cells can account fully for GCV nucleotide transfer. One report suggested that rat Novikoff hepatoma cells, which express connexin43 (Cx43), were able to take up membrane-impermeable dye from the culture medium through connexon hemichannels that did not align with hemichannels in neighboring cells to form functional GJIC (Li et al., 1996). If the Cx32 protein detected in SW620 cells represents functional hemichannels, this would be a potential mechanism for uptake of GCV nucleotides from the extracellular environment. We and others have demonstrated the excretion of low amounts of endogenous nucleotides from intact cells, and it is possible that such excretion combined with a mechanism for uptake accounts for the transfer of GCV nucleotides between neighboring cells (Dubyak and El-Montassim, 1993; Palmer et al., 1996). Such a mechanism for nucleotide transfer would depend on the proximity of neighboring cells, as reported here, since extracellular nucleotides would be rapidly diluted in the medium or degraded by enzymes in serum if the distance they had to traverse was too great. Further study is necessary to determine the exact mechanism for GCV nucleotide transfer in SW620 cells.

While there are several studies demonstrating the relevance of GJIC for bystander killing with HSV-TK/GCV, the studies presented here in SW620 cells provide strong evidence for the existence of a novel mechanism. Moreover, this bystander killing is mediated by nucleotide transfer. Depending on the exact mechanism responsible for this transfer, it is possible that it also contributes to bystander killing in cells that exhibit high levels of GJIC. Considering the importance of bystander killing in antitumor therapy with $\mathrm{HSV}-\mathrm{TK} / \mathrm{GCV}$ in vivo, complete identification and characterization of the process by which SW620 cells transfer GCV nucleotides is warranted.

\section{ACKNOWLEDGMENTS}

This work was supported in part by Grants CA46452 and CA72217 from the National Cancer Institute. Its contents are the responsibility solely of the authors and do not necessarily represent the official views of the National Cancer Institute.

\section{REFERENCES}

AGBARIA, R., MULLEN, C.A., HARTMAN, N.R., COONEY, D.A., HAO, Z., BLAESE, R.M., and JOHNS, D.G. (1994). Effects of IMP dehydrogenase inhibitors on the phosphorylation of ganciclovir in MOLT- 4 cells before and after herpes simplex virus thymidine kinase gene transduction. Mol. Pharmacol. 45, 777-782.

BALZARINI, J., BOHMAN, C., and DECLERCQ, E. (1993). Differential metabolism of cytostatic $(E)$-5-(2-bromovinyl)-2'-deoxyuridine, 9-(1,3-dihydroxy-2-propoxymethyl)guanine, and other antiherpetic drugs on tumor cells transfected by the thymidine kinase gene of herpes simplex virus type 1 or type 2. J. Biol. Chem. 269, $6332-6337$.

Bl, W.L., PARYSEK, L.M., WARNICK, R., and STAMBROOK, P.J. (1993). In vitro evidence that metabolic cooperation is responsible for the bystander effect observed with HSVtk retroviral gene therapy. Hum. Gene Ther. 4, 725-731.

BIRON, K.K., STANAT, S.C., SORRELL, J.B., FYFE, J.A., KELLER, P.M., LAMBE, C.U., and NELSON, D.J. (1985). Metabolic activation of the nucleoside analog 9-\{[2-hydroxy-1-(hydroxymethyl)ethoxy]methyl $\}$ guanine in human diploid fibroblasts infected with human cytomegalovirus. Proc. Natl. Acad. Sci. U.S.A. 82, 24732477.

BRIDGEWATER, J.A., SPRINGER, C.J., KNOX, R.J., MINTON, N.P., MICHAEL, N.P., and COLLINS, M.K. (1995). Expression of the bacterial nitroreductase enzyme in mammalian cells renders them selectively sensitive to killing by the prodrug CB1954. Eur. J. Cancer 31A, 2362-2370.

CARUSO, M., PANIS, Y., GAGANDEEP, S., HOUSSIN, D., SALZMANN, J.-L., and KLATZMANN, D. (1993). Regression of established macroscopic liver metastases after in situ transduction of a suicide gene. Proc. Natl. Acad. Sci. U.S.A. 90, 7024-7028.

COLOMA, M.J., HASTINGS, A., WIMS, L.A., and MORRISON, S.L. (1992). Novel vectors for the expression of antibody molecules using variable regions generated by polymerase chain reactions. J. Immunol. Methods 152, 89-104.

DIMAIO, J.M., CLARY, B.M., VIA, D.F., COVENEY, E., PAPPAS, T.N., and LYERLY, H.K. (1994). Directed enzyme pro-drug gene therapy for pancreatic cancer in vivo. Surgery 116, 205-213.

DUBYAK, G.R., and EL-MOATASSIM, C. (1993). Signal transduction via $\mathrm{P}_{2}$-purinergic receptors for extracellular ATP and other nucleotides. Am. J. Physiol. 265, C577-C606.

EASTHAM, J.A., CHEN, S., SEHGAL, I., YANG, G., TIMME, T.L., HALL, S.J., WOO, S.L.C., and THOMPSON, T.C. (1996). Prostate cancer gene therapy: Herpes simplex virus thymidine kinase gene transduction followed by ganciclovir in mouse and human prostate cancer models. Hum. Gene Ther. 7, 515-523.

EZZEDDINE, Z.D., MARTUZA, R.L., PLATIKA, D., SHORT, M.P., MALICK, A., CHOI, B., and BREAKEFIELD, X.O. (1991). Selective killing of glioma cells in culture and in vivo by retrovirus transfer of the herpes simplex virus thymidine kinase gene. New Biol. 3 , 608-614.

FAULDS, D., and HEEL, R.C. (1990). Ganciclovir: A review of its antiviral activity, pharmacokinetic properties and therapeutic efficacy in cytomegalovirus infections. Drugs 39, 597-638.

FICK, J., BARKER, F.G.I., DAZIN, P., WESTPHALE, E.M., BEYER, E.C., and ISRAEL, M.A. (1995). The extent of heterocellular com- 
munication mediated by gap junctions is predictive of bystander tumor cytotoxicity in vitro. Proc. Natl. Acad. Sci. U.S.A. 92, 11071-11075.

FIELD, A.K., DAVIES, M.E., DEWITT, C., PERRY, H.C., LIOU, R., GERMERSHAUSEN, J., KARKAS, J.D., ASHTON, W.T., JOHNSTON, D.B.R., and TOLMAN, R.L. (I983). 9-[[2-Hydroxy-1-(hydroxymethyl)ethoxy]methyl]guanine: A selective inhibitor of herpes group virus replication. Proc. Natl. Acad. Sci. U.S.A. 80, 4139-4143.

FREEMAN, S.M., ABBOUD, C.N., WHARTENBY, K.A., PACKMAN, C.H., KOEPLIN, D.S., MOOLTEN, F.L., and ABRAHAM, G.N. (1993). The "bystander effect": Tumor reression when a fraction of the tumor mass is genetically modified. Cancer Res. 53, 5274-5283.

FREEMAN, S.M., RAMESH, R., SHASTRI, M., MUNSHI, A., JENSEN, A.K., and MARROGI, A.J. (1995). The role of cytokines in mediating the bystander effect using HSV-TK xenogeneic cells. Cancer Lett. 92, 167-174.

GRIFFITHS, G.M., BEREK, C., KAARTINEN, M., and MILSTEIN, C. (1984). Somatic mutation and maturation of immune response to 2-phenyl-oxazolone. Nature (London) 312, 271-275.

HIRSCHOWITZ, E.A., OHWADA, A., PASCAL, W.R., RUSSI, T.J., and CRYSTAL, R.G. (1995). in vivo adenovirus-mediated gene transfer of the Escherichia coli cytosine deaminase gene to human colon carcinoma-derived tumors induces chemosensitivity to 5-fluorocytosine. Hum. Gene Ther. 6, 1055-1063.

HOOGENBOOM, H.R., GRIFFITHS, A.D., JOHNSON, K.S., CRISWELL, D.J., HUDSON, P., and WINTER, G. (1991). Multisubunit proteins on the surface of filamentous phage: Methodologies for displaying antibody (Fab) heavy and light chains. Nucleic Acids Res. 19, 4133-4137.

HUBER, B.E., RICHARDS, C.A., and KRENITSKY, T.A. (1991). Retroviral-mediated gene therapy for the treatment of hepatocellular carcinoma: An innovative approach for cancer therapy. Proc. Natl. Acad. Sci. U.S.A. 88, 8039-8043.

HUBER, B.E., AUSTIN, E.A., GOOD, S.S., KNICK, V.C., TIBBELS, S., and RICHARDS, C.A. (1993). In vivo antitumor activity of 5fluorocytosine on human colorectal carcinoma cells genetically modified to express cytosine deaminase. Cancer Res. 53, 4619-4626.

IDO, A., NAKATA, K., KATO, Y., NAKAO, K., MURATA, K., FUJTA, M., ISHII, N., TAMAOKI, T., SHIKU, H., and NAGATAKl, S. (1995). Gene therapy for hepatoma cells using a retrovirus vector carrying herpes simplex virus thymidine kinase gene under the control of human $\alpha$-fetoprotein gene promoter. Cancer Res. 55, 3105-3109.

ILSLEY, D.D., LEE, S.-H., MILLER, W.H., and KUCHTA, R.D. (1995). Acyclic guanosine analogs inhibit DNA polymerases $\alpha, \delta$, and $\epsilon$ with very different potencies and have unique mechanisms of action. Biochemistry 34, 2504-2510.

ISHII-MORITA, H., AGBARIA, R., MULLEN, C.A., HIRANO, H., KOEPLIN, D.A., RAM, Z., OLDFIELD, E.H., and JONES, D.G. (1997). Mechanism of "bystander effect" killing in the herpes simplex thymidine kinase gene therapy model of cancer treatment. Gene Ther. 4, 244-251.

KANKEO, S., HALLENBECK, P., KOTANI, T., NAKABAYASHI, H., MCGARRITY, G., TAMAOKI, T., FRENCH ANDERSON, W., and CHIANG, Y.L. (1996). Adenovirus-mediated gene therapy of hepatocellular carcinoma using cancer-specific gene expression. Cancer Res. 55, 5283-5287.

LI, H., LIU, T., LAZRAK, A., PERACCHIA, C., GOLDBERG, G.S., LAMPE, P.D., and JOHNSON, R.G. (1996). Properties and regulation of gap junctional hemichannels in the plasma membranes of cultured cells. J. Cell Biol. 134, 1019-1030.

LIM, K., and CHAE, C.B. (1989). A simple assay for DNA transfection by incubation of the cells in culture dishes with substrates for beta-galactosidase. BioTechniques 7, 576-579.

MAHONY, W.B., DOMIN, B.A., and ZIMMERMAN, T.P. (1991).
Ganciclovir permeation of the human erythrocyte membrane. Biochem. Pharmacol. 41, 263-271.

MARSHALKO, S.J., SCHWEITZER, B.l., and BEARDSLEY, G.P. (I995). Chiral chemical synthesis of DNA containing (S)-9-(1,3-dihydroxy-2-propoxymethyl) guanine (DHPG) and effects on thermal stability, duplex structure, and thermodynamics of duplex formation. Biochemistry 34, 9235-9248.

MARTIN, J.C., DVORAK, C.A., SMEE, D.F., MATTHEWS, T.R., and VERHEYDEN, J.P.H. (1983). 9-[(1,3-Dihydroxy-2-propoxy)methyl gguanine: A new potent and selective antiherpes agent. J. Med. Chem. 26, 759-761.

MESNIL, M., PICCOLI, C., KLEIN, J.-L., MORAND, I., and YAMASAKI, H. (I993). Lack of correlation between the gap junctional communication capacity of human colon cancer cell lines and expression of the DCC gene, a homologue of a cell adhesion molecule (N-CAM). Jpn. J. Cancer Res. 84, 742-747.

MESNIL, M., PICCOLI, C., TIRABY, G., WILLECKE, K., and YAMASAKI, H. (1996). Bystander killing of cancer cells by herpes simplex virus thymidine kinase gene is mediated by connexins. Proc. Natl. Acad. Sci. U.S.A. 93, 1831-1835.

MOOLTEN, F.L. (1986). Tumor chemosensitivity conferred by inserted herpes thymidine kinase genes: Paradigm for a prospective cancer control strategy. Cancer Res. 46, 5276-5281.

MOOLTEN, F.L. (1994). Drug sensitivity ("suicide") genes for selective cancer chemotherapy. Cancer Gene Ther. 1, 279-287.

MULLEN, C.A., KILSTRUP, M., and BLAESE, R.M. (1992). Transfer of the bacterial gene for cytosine deaminase to mammalian cells confers lethal sensitivity to 5-fluorocytosine: A negative selection system. Proc. Natl. Acad. Sci. U.S.A. 89, 33-37.

O'MALLEY, B.W., JR., CHEN, S.-H., SCHWARTZ, M.R., and WOO, S.L.C. (1995). Adenovirus-mediated gene therapy for human head and neck squamous cell cancer in a nude mouse model. Cancer Res. 55, 1080-1085.

PALMER, R.K., YULE, D.I., SHEWACH, D.S., WILLIAMS, J.A., and FISHER, S.K. (1996). Paracrine mediation of calcium signaling in human SK-MCIXC neuroepithelioma cells. Am. J. Physiol. 271, C43-C53.

PITTS, J.D. (1994). Cancer gene therapy: A bystander effect using the gap junctional pathway. Mol. Carcinogen. 11, 127-130.

RAM, Z., CULVER, K.W., WALBRIDGE, S., BLAESE, R.M., and OLDFIELD, E.H. (1993). In situ retroviral-mediated gene transfer for the treatment of brain tumors in rats. Cancer Res. 53, 83-88.

RAMESH, R., MARROGI, A.J., MUNSHI, A., ABBOUD, C.N., and FREEMAN, S.M. (1996). In vivo analysis of the "bystander effect": A cytokine cascade. Exp. Hematol. 24, 829-838.

REARDON, J.E. (1989). Herpes simplex virus type 1 and human DNA polymerase interactions with $2^{\prime}$-deoxyguanosine 5 '-triphosphate analogues. J. Biol. Chem. 264, 19039-19044.

REID, R., MAR, E.-C., HUANG, E.S., and TOPAL, M.D. (1988). Insertion and extension of acyclic, dideoxy, and ara nucleotides by herpesviridae, human $\alpha$ and human $\beta$ polymerases. J. Biol. Chem. 263, 3898-3904

REN, P., DE FEIJTER, W., PAUL, D.L., and RUCH, R.J. (1994). Enhancement of liver cell gap junction protein expression by glucocorticoids. Carcinogenesis 15, 1807-1813.

ROTH, J.A., and CRISTIANO, R.J. (1997). Gene therapy for cancer: What have we done and where are we going? J. Natl. Cancer. Inst. 89, 21-39.

RUCH, R.J. (1994). The role of gap junctional intercellular communication in neoplasia. Ann. Clin. Lab. Sci. 24, 216-231.

SAMEJIMA, Y., and MERUELO, D. (1995). "Bystander killing" induces apoptosis and is inhibited by forskolin. Gene Ther. 2, 50-58.

SHEWACH, D.S., HAHN, T.M., CHANG, E., HERTEL, L.W., and LAWRENCE, T.S. (1994a). Metabolism of 2',2'-difluoro-2'-deoxycytidine and radiation sensitization of human colon carcinoma cells. Cancer Res. 54, 3218-3223. 
SHEWACH, D.S., ZERBE, L.K., HUGHES, T.L., ROESSLER, B.J., BREAKEFIELD, X.O., and DAVIDSON, B.L. (1994b). Enhanced cytotoxicity of antiviral drugs mediated by adenovirus directed transfer of the herpes simplex virus thymidine kinase gene in rat glioma cells. Cancer Gene Ther. 1, 107-112.

SMEE, D.F., BOEHME, R., CHERNOW, M., BINKO, B.P., and MATTHEWS, T.R. (1985). Intracellular metabolism and enzymatic phosphorylation of 9-(1,3-dihydroxy-2-propoxymethyl)guanine and acyclovir in herpes simplex virus-infected and uninfected cells. Biochem. Pharmacol. 34, 1049-1056.

St. Clair, M.H., Lambe, C.U., and Furman, P.A. (1987). Inhibition by ganciclovir of cell growth and DNA synthesis of cells biochemically transformed with herpesvirus genetic information. Antimicrob. Agents Chemother. 31, 844-849.

VILE, R.G., and HART, I.R. (1993). Use of tissue-specific expression of the herpes simplex virus thymidine kinase gene to inhibit growth of established murine melanomas following direct intratumoral injection of DNA. Cancer Res. 53, 3860-3864.

VINCENT, A.J.P.E., VOGELS, R., SOMEREN, G.C., ESANDI, M.C., NOTEBOOM, J.L., AVEZAAT, C.J.J., VECHT, C., BEKKUM, D.W.V., VALERIO, D., BOUT, A., and HOOGERBRUGGE, P.M. (1996). Herpes simplex virus thymidine kinase gene therapy for rat malignant brain tumors. Hum. Gene Ther. 7, 197-205.

WU, J.K., CANO, W.G., MEYLAERTS, S.A.G., QI, P., VRIONIS, F., and CHERINGTON, V. (1994). Bystander tumoricidal effect in the treatment of experimental brain tumors. Neurosurgery 35, $1094-1103$.

YEAGER, M., and NICHOLSON, B.J. (1996). Structure of gap junction intercellular channels. Curr. Opin. Struct. Biol. 6, 183-192.

YOSHIDA, K., KAWAMI, H., YAMAGUCHI, Y., KUNIYASU, H., NISHIYAMA, M., HIRAI, T., YANAGIHARA, K., TAHARA, E., and TOGE, T. (1995). Retrovirally transmitted gene therapy for gastric carcinoma using herpes simplex virus thymidine kinase gene. Cancer 75, 1467-1471.

ZAR, J.H. (1974). Biostatistical Analysis. McElroy, W.D., and Swanson, C.P. eds. (Prentice-Hall, Englewood Cliffs, NJ).

\author{
Address reprint requests to: \\ Dr. Donna S. Shewach \\ 4713 Upjohn Center \\ University of Michigan Medical Center \\ 1310 East Catherine \\ Ann Arbor, MI 48109-0504
}

Received for publication September 23, 1997; accepted after revision January 28, 1998. 
This article has been cited by:

1. J J O'Konek, P D Boucher, A A Iacco, T E Wilson, D S Shewach. 2009. MLH1 deficiency enhances tumor cell sensitivity to ganciclovir. Cancer Gene Therapy . [CrossRef]

2. Sanjay Dhar, Michael P. McConnell, Nareg A. Gharibjanian, Christine M. Young, Jason M. Rogers, Thang D. Nguyen, Gregory R.D. Evans . 2007. Herpes Simplex Virus-Thymidine Kinase-Based Suicide Gene Therapy as a "Molecular Switch Off" for Nerve Growth Factor Production In VitroHerpes Simplex Virus-Thymidine Kinase-Based Suicide Gene Therapy as a "Molecular Switch Off” for Nerve Growth Factor Production In Vitro. Tissue Engineering 13:9, 2357-2365. [Abstract] [PDF] [PDF Plus]

3. Bruce J. Baum, Simon D. Tran. 2006. Synergy between genetic and tissue engineering: creating an artificial salivary gland. Periodontology 2000 41:1, 218-223. [CrossRef]

4. B G Gentry, M Im, P D Boucher, R J Ruch, D S Shewach. 2005. GCV phosphates are transferred between HeLa cells despite lack of bystander cytotoxicity. Gene Therapy 12:13, 1033-1041. [CrossRef]

5. Yan Zhang, Shu-Zhen Huang, Shu Wang, Yi-Tao Zeng. 2005. Development of an HSV-tk transgenic mouse model for study of liver damage. FEBS Journal 272:9, 2207-2215. [CrossRef]

6. Sophie Deharvengt, S??verine Wack, Muriel Uhring, Marc Aprahamian, Amor Hajri. 2004. Suicide Gene/Prodrug Therapy for Pancreatic Adenocarcinoma by E. Coli Purine Nucleoside Phosphorylase and 6-Methylpurine 2???-deoxyriboside. Pancreas 28:2, e54-e64. [CrossRef]

7. Eliana Greco, Paola Fogar, Daniela Basso, Anna Stefani, Filippo Navaglia, Carlo-Federico Zambon, Saverio Mazza, Nicoletta Gallo, Maria Piva, Aldo Scarpa, Sergio Pedrazzoli, Mario Plebani. 2002. Pancreas 25:2, e21-e29. [CrossRef]

8. Donna S. Shewach , Patrick J. Murphy, Blaine W. Robinson, Jennifer Vuletich, Paul D. Boucher , Anna L. Blobaum , Laura Zerbe, John A. Secrist III, William B. Parker . 2002. Multi-Log Cytotoxicity of Carbocyclic 2'-Deoxyguanosine in HSV-TK-Expressing Human Tumor CellsMulti-Log Cytotoxicity of Carbocyclic 2'-Deoxyguanosine in HSV-TK-Expressing Human Tumor Cells. Human Gene Therapy 13:4, 543-551. [Abstract] [PDF] [PDF Plus]

9. Doron J. Aframian, Changyu Zheng, Corinne M. Goldsmith , Janeta Nikolovski, Edna Cukierman, Kenneth M. Yamada , David J. Mooney, Henning Birkedal-Hansen , Bruce J. Baum . 2001. Using HSV-Thymidine Kinase for Safety in an Allogeneic Salivary Graft Cell LineUsing HSV-Thymidine Kinase for Safety in an Allogeneic Salivary Graft Cell Line. Tissue Engineering 7:4, 405-413. [Abstract] [PDF] [PDF Plus]

10. Tetsuya Okino, Masahiko Onda, Norio Matsukura, Ken-iti Inada, Masae Tatematsu, Satoru Suzuki, Takashi Shimada. 2001. Sequential Histopathological Changes in vivo after Suicide Gene Therapy of Gastric Cancer Induced by N-Methyl-N'-nitro-N-nitrosoguanidine in Rats. Cancer Science 92:6, 673-679. [CrossRef]

11. Shuji Akasaka, Satoru Suzuki, Hiroyuki Shimizu, Takehito Igarashi, Masao Akimoto, Takashi Shimada. 2001. Suicide Gene Therapy for Chemically Induced Rat Bladder Tumor Entailing Instillation of Adenoviral Vectors. Cancer Science 92:5, 568-575. [CrossRef]

12. Oliver Wildner, John C. Morris. 2000. Therapy of peritoneal carcinomatosis from colon cancer with oncolytic adenoviruses. The Journal of Gene Medicine 2:5, 353-360. [CrossRef]

13. Jian Qiao , Margaret E. Black, Manuel Caruso . 2000. Enhanced Ganciclovir Killing and Bystander Effect of Human Tumor Cells Transduced with a Retroviral Vector Carrying a Herpes Simplex Virus Thymidine Kinase Gene MutantEnhanced Ganciclovir Killing and Bystander Effect of Human Tumor Cells Transduced with a Retroviral Vector Carrying a Herpes Simplex Virus Thymidine Kinase Gene Mutant. Human Gene Therapy 11:11, 1569-1576. [Abstract] [PDF] [PDF Plus]

14. Oliver Wildner, R. Michael Blaese, John C. Morris . 1999. Synergy between the Herpes Simplex Virus tk/Ganciclovir Prodrug Suicide System and the Topoisomerase I Inhibitor TopotecanSynergy between the Herpes Simplex Virus tk/Ganciclovir Prodrug Suicide System and the Topoisomerase I Inhibitor Topotecan. Human Gene Therapy 10:16, 2679-2687. [Abstract] [PDF] [PDF Plus]

15. Robyn A. McMasters, Robert L. Saylors, Kelly E. Jones, Michael E. Hendrix, Mary Pat Moyer, Richard R. Drake. 1998. Lack of Bystander Killing in Herpes Simplex Virus Thymidine Kinase-Transduced Colon Cell Lines Due to Deficient Connexin43 Gap Junction FormationLack of Bystander Killing in Herpes Simplex Virus Thymidine 
Kinase-Transduced Colon Cell Lines Due to Deficient Connexin43 Gap Junction Formation. Human Gene Therapy 9:15, 2253-2261. [Abstract] [PDF] [PDF Plus] 